\title{
Anthropometric Indices for the Prediction of Metabolic Syndrome and its Features, among Children and Adolescents
}

\author{
Deepika Bahl ${ }^{1 *}$, Kalyani Singh ${ }^{1}$, Manisha Sabharwal ${ }^{1}$ and Monika Arora ${ }^{2}$ \\ 'Department of Foods and Nutrition, Lady Irwin College, Sikandara Road New Delhi 110001, \\ India; bahl.deepa@gmail.com \\ ${ }^{2}$ Health Promotion and Tobacco Control and Adjunct Assistant Professor Public Health \\ Foundation of India, Delhi, India
}

\begin{abstract}
Metabolic syndrome refers to cluster of cardiovascular diseases risk factors, not only seen in adults but in children and adolescents too. Though in children and adolescents its prevalence is not as high as among adults, the existence even in low percentage poses greater economic burden and hurdle to national development. Identification of subjects with this syndrome can only be done if data on anthropometry (height, weight or waist circumference, blood pressure) and biochemical (fasting blood glucose, High density lipoprotein triglycerides) is available. But biochemical estimation especially in children and adolescents is difficult due to its poor acceptance because of its invasive nature. Thus, it leads to non recognition of this syndrome. Therefore there is a need to build up a strategy where in these young age group are not ignored by health professionals. Based on review, prevalence is higher among overweight and obese subjects in comparison to normal weight. Overweight and obese subjects should be screened through the use of anthropometric measurements such as waist circumference, body mass index, waist to height ratio and neck circumference. Screened subjects then should be subjected to invasive techniques for confirmation of syndrome. This process of prediction will be cost effective and also the high risk subject will not be ignored. Anthropometric indices have different sensitivity and specificity to predict metabolic syndrome at a younger age but the index was found to be significantly correlated with Metabolic syndrome is waist circumference.
\end{abstract}

Keywords: Adolescents, CVD Risk Factors Children, Metabolic Syndrome

\section{Introduction}

In the field of medical science, Metabolic Syndrome (MS) has become one of the most frequently used terms ${ }^{1}$. Its presence in an individual illustrates the constellation of Cardiovascular Disease (CVD) risk factors like hypertension, obesity, elevated triglycerides, low HDL cholesterol (altered lipid levels) and glucose intolerance ${ }^{2}$. Various international organizations and expert groups such as the World Health Organization (WHO), European Group for the study of Insulin Resistance (EGIR), National Cholesterol Education Program Adult Treatment Panel (NCEP ATP), American Association of Clinical Endocrinology (AACE), International Diabetes Federation (IDF) and American Heart Association/National Heart, Lung, and Blood Institute, have attempted to define $\mathrm{MS}^{1}$. From all the definitions, modified NCEP ATP III (2003) and IDF definitions (2007) (Table 1) have a universal appeal as the components in it could be easily measured in any small clinic or laboratory in a developing country at a very low $\operatorname{cost}^{3}$.

${ }^{*}$ Author for correspondence 
Table 1. IDF and NCEP definition of MS for children and adolescents

\begin{tabular}{lcc}
\hline CVD Risk factors & $\begin{array}{c}\text { International } \\
\text { Diabetic Federation } \\
(\text { IDF })^{4}\end{array}$ & $\begin{array}{c}\text { NCEP ATP } \\
\text { III modified } \\
\text { as per age }\end{array}$ \\
\hline Waist & $\geq 90^{\text {th }}$ percentile & $>90^{\text {th }}$ \\
circumference & percentile \\
Blood pressure & $\mathrm{SBP} \geq 130$ or DBP $\geq$ & $>90^{\text {th }}$ \\
& $85 \mathrm{mmHg}$ or taking \\
anti hypertensive & percentile \\
drug & $\leq 40$ & \\
HDL $-\mathrm{C}(\mathrm{mg} / \mathrm{dl})$ & $\geq 150$ & $\leq 40$ \\
Triglyceride $(\mathrm{mg} / \mathrm{dl})$ & $\geq 100$ & $\geq 110$ \\
Glucose $(\mathrm{mg} / \mathrm{dl})$ & Central obesity +2 or & 3 or more \\
Diagnosis & more criteria & among 5 \\
& & criteria \\
\hline
\end{tabular}

NCEP ATP III: National Cholesterol Education Program Adult Treatment Panel III, SBP: Systolic Blood Pressure, DBP: Diastolic Blood pressure, HDL-C: High Density Lipoprotein Cholesterol

\subsection{Metabolic Syndrome and Economic} Aspect

Occurrence of MS is increasing at a striking rate worldwide $^{6}$ with a simultaneous increase in childhood obesity among both genders and all racial, ethnic and socioeconomic groups ${ }^{7}$. Presence of MS in an adult is associated with a 2-fold higher risk of CVD and a 5-fold higher risk of diabetes and has a $30 \%-40 \%$ probability of developing diabetes and/or CVD within 20 years as compared to subjects without $\mathrm{MS}^{8}$. Progression of MS to this disease have an impact on the overall growth and economy of a country both in direct and indirect ways. Direct cost includes impact on families, healthcare sectors including consultation, investigations, medications, management, hospitalization, treating complications, transportation and time utilized for care in case of nonmedical expenses. Indirect cost includes impact on society and government, which are related to productivity costs, work days lost, low productivity, disability payment, social security and depression'. In 2005, loss in national income from heart disease, stroke and diabetes was estimated for various countries; for instance 18 billion dollars in China, 9 billion dollars in India, and 2.7 billion dollars in Brazil and the estimates for the same countries for year 2015 are 3 to 7 times higher than year $2005^{10}$.

Recently, estimations for economic impact of Non Communicable Disease (NCD) on India have been made for year 2012-2030. Total losses associated with five major NCD (diabetes, CVD, respiratory disease, cancer and mental health) was USD 2.6 trillion. But the CVD was estimated to cause maximum loss i.e. USD 1.21 trillion ${ }^{11}$. Thus emphasizing it requires constant attention.

\subsection{Metabolic Syndrome No More an Adult Problem}

There are many studies done globally with adults as subjects and high prevalence of MS has been reported but recent trends are changing; MS is now being seen in children and adolescents too. These trends were visible in developed countries before developing countries (Table 2). Among developed countries higher prevalence has been seen in overweight and obese children and adolescents in comparison to those of normal weight. Among developing countries, similar trends have been seen. Although from developing countries maximum studies have been reported from India. As per Indian data, prevalence is much higher in overweight and obese children and adolescents, though it may exist in adolescent with normal weight. Though this situation may be hidden but it is a significant problem.

Prevalence of MS among children and adolescents around the world is $10 \%$, ranging from near $2 \%$ among normal weight children and adolescents to about $32 \%$ among the obese ${ }^{12}$. Children as young as 4 and 6 years old have been identified with MS in India and Thailand ${ }^{13,14}$. This situation may be attributed to demographic and lifestyle changes due to recent nutrition transition, urbanization, industrialization, and overpowering globalization' ${ }^{9}$ Various determinants have been identified for MS in children and adolescents and they are socio economic status, family history of hypertension, higher Body Mass Index (BMI)/ obesity ${ }^{15}$ and low birth weight ${ }^{16,17}$. But the factor responsible for maximum variance in clustering and causing MS is obesity ${ }^{18}$. In a British cohort followed up for 57 years, obesity in childhood was associated with 1.5 times increased risk of all-cause mortality and two-fold increased risk of ischemic heart disease ${ }^{19}$. Obesity in children and adolescents is mainly attributed to unhealthy diet and sedentary lifestyle ${ }^{20}$.

\subsection{Prediction of Metabolic Syndrome}

Keeping in view the increasing prevalence of MS around the globe and the economic loss contributed by the progression of MS to deadly diseases (CVD and diabetes), 
Table 2. Prevalence of Metabolic Syndrome among children and adolescents in developed and developing countries

\begin{tabular}{|c|c|c|c|}
\hline $\begin{array}{l}\text { Author, year and } \\
\text { country }\end{array}$ & Age, sample Size & $\begin{array}{c}\text { Definition of metabolic } \\
\text { syndrome }\end{array}$ & $\begin{array}{c}\text { Prevalence according } \\
\text { to criteria used }\end{array}$ \\
\hline \multicolumn{4}{|l|}{ Developing Countries } \\
\hline $\begin{array}{l}\text { Rizzo et al. }{ }^{21} \\
\text { Brazil }\end{array}$ & $\begin{array}{c}10-16 \text { yrs } \\
321 \text { adolescents }\end{array}$ & IDF & $18.3 \%$ \\
\hline $\begin{array}{l}\text { Wang et al. }{ }^{22} \\
\text { China }\end{array}$ & $\begin{array}{l}6-18 \text { yrs } \\
3373 \text { children and } \\
\text { adolescents }\end{array}$ & $\begin{array}{c}\text { IDF } \\
\text { Modified NCEP }\end{array}$ & $\begin{array}{c}\text { Obese: } 14.3 \% \text {, } \\
\text { Overweight: } 3.7 \% \\
\text { Obese: } 32.3 \% \text {, } \\
\text { Overweight: } 8.4 \%\end{array}$ \\
\hline $\begin{array}{l}\text { Li et al. } .^{23} \\
\text { China }\end{array}$ & $\begin{array}{l}15-19 \text { yrs } \\
2761 \text { adolescents }\end{array}$ & De Ferranti & Overall: $3.7 \%$ \\
\hline $\begin{array}{l}\text { Singh et al. }{ }^{15} \\
\text { India }\end{array}$ & $\begin{array}{c}12-17 \text { yrs } \\
1083 \text { Adolescents }\end{array}$ & Modified NCEP ATP ${ }^{5}$ & Overall: $4.2 \%$ \\
\hline $\begin{array}{l}\text { Gupta et al. }{ }^{24} \\
\text { India }\end{array}$ & $\begin{array}{c}15-18 \text { yrs } \\
1292 \text { adolescents }\end{array}$ & $\begin{array}{l}\text { Modified NCEP } 5 \text { with } \\
\text { triglyceride } \geq 150 \mathrm{mg} / \mathrm{dl}\end{array}$ & $\begin{array}{l}0.0 \% \text { in male and } \\
0.2 \% \text { in females }\end{array}$ \\
\hline $\begin{array}{l}\text { Kapil and Kaur }{ }^{14} \\
\text { India }\end{array}$ & $\begin{array}{l}\text { 6-18 yrs } 1331 \\
\text { children \& Adolescents }\end{array}$ & $\begin{array}{l}\text { IDF with blood pressure } \\
\geq 95^{\text {th }} \text { percentile for age } \\
\text { and sex }, 2007\end{array}$ & $\begin{array}{l}6.5 \% \text { (males } 6.9 \% \text { and } \\
\text { females } 5.9 \% \text { ) }\end{array}$ \\
\hline $\begin{array}{l}\text { Yatheesha et al. }{ }^{25} \\
\text { India }\end{array}$ & $\begin{array}{l}81 \text { children \& adolescents } \\
\text { risk of overweight \& } \\
\text { overweight }\end{array}$ & Modified NCEP ${ }^{5}$ & $25.9 \%$ \\
\hline $\begin{array}{l}\text { Saha et al } .^{26} \\
\text { India }\end{array}$ & $\begin{array}{l}\text { 6-11 yrs } 49 \text { obese } \\
\text { children }\end{array}$ & Ferranti et al, 2004 & $14.3 \%$ \\
\hline $\begin{array}{l}\text { Singh et al. }{ }^{27} \\
\text { India }\end{array}$ & $\begin{array}{c}10-18 \text { yrs } \\
116 \text { adolescents }\end{array}$ & Modified NCEP 5 & $\begin{array}{c}\text { Overall :2.67\% } \\
\text { Males } 3.8 \% \\
\text { females } 1.62 \%\end{array}$ \\
\hline $\begin{array}{l}\text { Andrabi et al. }{ }^{28} \\
\text { India }\end{array}$ & $\begin{array}{c}\text { 8-18 yrs } 758 \text { children \& } \\
\text { Adolescents }\end{array}$ & Modified NCEP ${ }^{5}$ & $\begin{array}{c}\text { Overall :3.8\% } \\
\text { Male : } 3.9 \% \\
\text { females : } 3.8 \%\end{array}$ \\
\hline $\begin{array}{l}\text { Malonda and } \\
\text { Tangklilisan } \\
\text { Tndonesia }\end{array}$ & $\begin{array}{c}10-14 \text { yrs } 30 \text { obese \& } 30 \\
\text { overweight }\end{array}$ & Modified NCEP ${ }^{5}$ & $\begin{array}{c}13 \text { obese and } 3 \\
\text { overweight subjects } \\
\text { had MS }\end{array}$ \\
\hline $\begin{array}{l}\text { Esmaillzadeh et al. } .^{30} \\
\text { Iran }\end{array}$ & $\begin{array}{c}3,036 \\
10-19 \text { year adolescents }\end{array}$ & Modified NCEP ${ }^{5}$ & $\begin{array}{l}\text { 0verall: } 10.1 \% \\
\text { Males:10.3\% } \\
\text { Females:9.9\% }\end{array}$ \\
\hline $\begin{array}{l}\text { Kelishadi et al. }{ }^{31} \\
\text { Iran }\end{array}$ & $\begin{array}{c}6-18 \text { yrs } \\
4811 \text { children and } \\
\text { adolescents }\end{array}$ & $\begin{array}{l}\text { Modified ATP III criteria } \\
\text { (8), but fasting blood } \\
\text { glucose } 100 \mathrm{mg} / \mathrm{dl}\end{array}$ & $\begin{array}{l}\text { Overall: } 14.1 \% \\
\text { Males: } 15 \% \\
\text { Females: } 11 \%\end{array}$ \\
\hline $\begin{array}{l}\text { Barzin et al. }{ }^{32} \\
\text { Iran }\end{array}$ & $\begin{array}{c}11-18 \text { yrs } \\
1100 \text { adolescents }\end{array}$ & IDF & $\begin{array}{l}\text { Males:25.5\% } \\
\text { Females: } 1.8 \%\end{array}$ \\
\hline $\begin{array}{l}\text { Wee et al. }{ }^{33} \\
\text { Malaysia }\end{array}$ & $\begin{array}{c}\text { 9-12 yrs } 402 \text { children } \\
\text { (193-Normal weight, } 209 \\
\text { overweight / obese) }\end{array}$ & IDF & $\begin{array}{l}5.3 \% \text { of the } \\
\text { overweight/obese } \\
\text { children }\end{array}$ \\
\hline $\begin{array}{l}\text { Cook et al. }{ }^{5} \\
\text { United States }\end{array}$ & $\begin{array}{c}12-19 \text { yrs } \\
2430 \text { Adolescents }\end{array}$ & Modified NCEP & $\begin{array}{l}\text { Overall- } 4.2 \% \\
\text { Males }-6.1 \% \\
\text { Females-2.1\% }\end{array}$ \\
\hline
\end{tabular}




\begin{tabular}{|c|c|c|c|}
\hline \multicolumn{4}{|l|}{ Developed countries } \\
\hline $\begin{array}{l}\text { Cruz et al. }{ }^{34} \\
\text { United States }\end{array}$ & $\begin{array}{c}8-19 \text { yrs } \\
126 \text { overweight children }\end{array}$ & Modified NCEP & $\begin{array}{c}\text { Risk of } \\
\text { overweight }\left(85-95^{\text {th }}\right. \\
\text { percentile of BMI }): \\
6.8 \% \\
\text { Overweight (BMI } \\
\geq 95 \text { th percentile ) } \\
: 28.7 \%\end{array}$ \\
\hline $\begin{array}{l}\text { Schumacher et al. }{ }^{35} \\
\text { United States }\end{array}$ & $\begin{array}{c}8-10 \text { yrs } \\
214 \text { overweight \& obese }\end{array}$ & Modified NCEP & Overall: $5.6 \%$ \\
\hline $\begin{array}{l}\text { Mehairi et al. }{ }^{36} \\
\text { United States }\end{array}$ & $\begin{array}{c}12-18 y r s \\
1018 \text { adolescents }\end{array}$ & IDF & $\begin{array}{l}\text { Males:21\% } \\
\text { Females: } 4 \%\end{array}$ \\
\hline $\begin{array}{l}\text { Sen et al. }{ }^{37} \\
\text { United Kingdom }\end{array}$ & $\begin{array}{c}2-19 \text { yrs } \\
352 \text { obese children and } \\
\text { adolescents }\end{array}$ & Modified NCEP & Overall: $41.8 \%$ \\
\hline $\begin{array}{l}\text { Moran et al. }{ }^{38} \\
\text { Mexico }\end{array}$ & $\begin{array}{c}10-18 \text { yrs } \\
965 \text { children and } \\
\text { adolescents }\end{array}$ & $\begin{array}{c}\text { ATP III , AACE , WHO, } \\
\text { EGIR }\end{array}$ & $\begin{array}{l}6.5 \%: \mathrm{ATP} \text { III } \\
7.7 \%: \mathrm{AACE} \\
4.5 \%: \mathrm{WHO} \\
3.8 \%: \mathrm{EGIR}\end{array}$ \\
\hline $\begin{array}{l}\text { Ryu et al. }{ }^{39} \\
\text { Korea }\end{array}$ & $\begin{array}{c}12-13 \text { yrs } \\
1393 \text { adolescents }\end{array}$ & Modified NCEP 5 & $\begin{array}{c}\text { Overall :5.5\% } \\
\text { Overweight :22.3\% }\end{array}$ \\
\hline $\begin{array}{l}\text { Kim et al. }{ }^{40} \\
\text { Korea }\end{array}$ & $\begin{array}{l}\text { South Korean adolescents } \\
\text { in } 1998 \text { and } 2001 ; \\
\text { numbers of subjects aged } \\
12-19 \text { years were } 1,317 \text { in } \\
1998 \text { and } 848 \text { in } 2001\end{array}$ & Modified NCEP ${ }^{5}$ & $\begin{array}{l}\text { 1998: } 6.8 \% \\
2001: 9.2 \%\end{array}$ \\
\hline $\begin{array}{l}\text { Seo et al. }{ }^{41} \\
\text { Korea }\end{array}$ & $\begin{array}{c}10-19 \text { yrs } \\
3431 \text { children and } \\
\text { adolescents }\end{array}$ & Modified NCEP ${ }^{5}$ & Overall: $5.3 \%$ \\
\hline $\begin{array}{l}\text { You and Son }{ }^{42} \\
\text { Korea }\end{array}$ & $\begin{array}{c}12-18 \text { yrs } \\
606 \text { adolescents }\end{array}$ & Modified NCEP ${ }^{5}$ & $\begin{array}{c}\text { Overall: } 13.0 \% \\
15.4 \% \text { boys } \\
10.0 \% \text { girls }\end{array}$ \\
\hline
\end{tabular}

need of the hour is predicting and identifying individuals with MS at early ages (children and adolescent) to reduce the burden of CVD and diabetes. The main contributor for increasing prevalence of MS is, growing obesity among children and adolescents ${ }^{43}$. Thus there is a need to identify these high risk subjects. Screening by use of biochemical testing is expensive, invasive and time consuming because testing involves detection of multiple risk factors ${ }^{44}$. However identifying subjects by anthropometry to delineate high risk subjects and further evaluation by blood testing and diagnosing MS is appropriate. Anthropometry had been selected as a measure of prediction due to its universal appeal, it is less expensive, less invasive, easy to use, more success rates, accurate to assess size ,composition and proportions of human body and in managing long term cardiovascular risk factors ${ }^{45,46}$. Anthropometric measures frequently used to assess overweight and obesity status among children and adolescents are Body Mass Index (BMI), Waist Circumference (WC), waist to height ratio and neck circumference ${ }^{47}$ and these measures are associated with MS and its features in children and adolescents ${ }^{48}$.

\subsubsection{Waist Circumference}

It is an index of abdominal obesity ${ }^{49}$. Various organisations and the expert groups have attempted to give information on waist measurement protocol. As per WHO, measurement should be made at the approximate midpoint 
between the lower margin of the last palpable rib and the top of the iliac crest $^{50}$. The United States (US) National Institutes of Health (NIH) protocol and the protocol used in the US National Health and Nutrition Examination Survey (NHANES) III indicated that it should be measured at the top of the iliac crest ${ }^{51,52}$. The NIH also provided a protocol for the measurement of waist circumference for the Multi-Ethnic Study of Atherosclerosis (MESA) study. This protocol indicates that the waist measurement should be made at the level of the umbilicus or navel. However, published reports indicate that measurements of waist circumference made at the level of the umbilicus may underestimate the true waist circumference ${ }^{53}$.

Once the prescribed protocol is followed, this measurement appears to be simple, effective and easier to obtain because of a single measurement and poses minimal participant burden because clothing needs to be removed only from the abdominal area and thus fits best in identifying children who are at risk of developing $\mathrm{MS}^{54}$. NCEP-ATP-III and IDF established increased WC as the basic criterion in the diagnosis of MS as the most effective anthropometric index ${ }^{(55,4)}$. Data from 22125 school children in Taiwan was studied and the evidence from the results made the author to conclude WC is the best predictor of metabolic abnormalities. To know the association, anthropometric measures (WC, hip circumference, arm girth, triceps skin fold, scapular thickness, wrist circumference and BMI) with metabolic abnormality by partial correlation were estimated from logistic regression. Higher the value of this statistical measure, higher was the degree of association between the two variables. The partial correlation was highest for WC (partial R2 $=10.69 \%$ ), followed by BMI (partial R2 $=9.80 \%$ ) and WC explained higher variance than BMI for the metabolic derangements ${ }^{49}$.Study with biracial samples (AfricanAmerican youths and Caucasian youths), proved WC as an independent correlate of daytime and night-time BP and dyslipidemia. Significant results were seen for WC correlation with Blood Pressure (BP) and Triglycerides (TG), High Density Lipoproteins (HDL), TG/HDL and Very-Low-Density Lipoprotein (VLDL) even after controlling for BMI percentiles; however BMI percentile did not correlate with $\mathrm{BP}$ and lipids after accounting for WC independent of race ${ }^{56}$. Similar results have been reported where WC has performed better than BMI in predicting abnormal cardio metabolic phenotypes among adolescents and supports the inclusion of WC in definition of $\mathrm{MS}^{(49,57)}$. Another study concluded that MS factors clustered significantly higher in children with WC greater than 90 percentile than in children with the waist circumference less than 90 percentile ${ }^{58}$. The result of study indicated that it was not predictive of MS whereas WC and BMI had shown the strongest association to predict $\mathrm{MS}^{46}$. According to Lee et al. ${ }^{59}$ where the WC threshold values/ percentiles for 938 adolescents (10-18 yrs) had been calculated for predicting metabolic risk factors. WC derived from ROC analysis were 55th and 32th percentiles in males and females 10-15 years of age, and $73 \mathrm{~cm}$ and $76 \mathrm{~cm}$ in males and females $16-18$ years of age, respectively. At these threshold percentiles/values for WC, $71-100 \%$ of adolescents were correctly classified as having two or more MS components (sensitivity) and $37-87 \%$ of them were correctly classified as not having two or more MS components (specificity) ${ }^{59}$. Data from Bogulas Heart involving 3000 children and adolescents of age 5-17 years analysed by Freedman et al concluded that WC may help in identifying children likely to have adverse concentration of lipids and insulin ${ }^{60}$. Similar strong correlation was seen in a cohort study involving Australian Aboriginal children and Italian children of age 3-11 years ${ }^{(58,61)}$. However the result was not similar, when the researcher included adolescents and young adults of age 14-25 years from New Delhi and came to the conclusion WC was inferior to BMI and subscapular skin fold thickness in identifying hyperinsulinemia in males and the presence of three or more risk factors of $\mathrm{MS}^{62}$. Gender difference has been seen in studies reported, amongst Taiwan male adolescents. WC was most significant variable associated with MS in males but not among female adolescents ${ }^{63}$.

WC has not only been used with adolescents for predicting MS but also with primary school children. A study was conducted by Hirschler et al. ${ }^{64}$ with 5,103 children age 4-13yrs and findings were summarized as waist circumference value of 75 th percentile could be the right and practical tool to identify young children at risk for future type 2 diabetes and cardiovascular disease ${ }^{64}$.Cerain precautions which need to be considered while measuring WC to maintain its specificity and sensitivity are appropriate anatomical placement of the measuring tape, its tightness and the type of tape used, the subject's posture, phase of respiration, abdominal tension, stomach contents and clothing ${ }^{65}$.

\subsubsection{Body Mass Index}

It represents weight to height ratio indicating body weight in relation to height ${ }^{66}$. It is widely used tool for 
the assessment of overweight and obesity among adults and children ${ }^{67}$ but its use in children and adolescents is still a controversial issue because it seems to give a limited insight of degree of excess body fat ${ }^{68}$. For correct interpretation, BMI measures have to be expressed as $\mathrm{z}$ scores or percentiles relative to age and sex, as BMI is strongly related to growth and maturation ${ }^{69}$. Although BMI is being routinely measured at all ages because of its prognostic significance ${ }^{70}$, is not an accurate measure of adiposity ${ }^{71}$.

BMI assessment is recommended by the American Academy of Pediatrics for the screening of adiposity related diseases ${ }^{72}$. As per American Diabetic association for early screening in children, BMI $>85^{\text {th }}$ percentile should be considered ${ }^{73}$. Evidence from the cross sectional study with 1,194 children of 9 years age which compared several anthropometric indices; triceps Skin-Fold Thickness (SFT), waist circumference, hip circumference, waist-to-hip ratio, body mass index and waist-to-height ratio and their association with metabolic syndrome. The study findings suggested age- and sex-specific cut off points of BMI could be used to screen $\mathrm{MS}^{74}$. Similar results were seen in a study by Garnett et al. ${ }^{75}$, in a cohort study including 315 children aged 7-8 years and were followed up after 7 years with 290 adolescents. The study concluded that BMI is a well-established measure in children to identify those at increased risk for CVD risk factors clustering in adolescents and there is no need to measure WC in addition to it. The author also stated other advantages such as less difficulty associated with BMI over WC which is a quick routine measure of height and weight, in contrast to WC measurements which involves locating bony landmarks (lower costal boarder and iliac crest), removal of clothing and careful placement of the tape measure to avoid fat rolls that can be uncomfortable, awkward, or embarrassing for the overweight and obese children ${ }^{75}$. Considering the advantages, the author concluded BMI is a most suitable index and have the predictive power similar to $\mathrm{WC}$ and it will be justifiable to use BMI percentile to define overweight and obesity in predicting MS among children and adolescents ${ }^{49}$. Along with advantages, BMI had a comparable or even better predictive value among 79 male Caucasian German 13-17 aged adolescents for identifying the components of MS or MS when compared with other anthropometric indices like waist circumference, waist to hip ratio and Waist to Height Ratio (WHtR) with respect to power ${ }^{76}$. As per the evidence from the study involving 1562 Taiwan adolescents aged 11-15 yrs, authors observed that BMI was the most significant variable amongst girls in association with terms of MS and body fat. Pearson's correlation coefficient of BMI and body fat was 0.95 in girls in comparison to 0.81 in boys ${ }^{63}$. Based on the evidence of the cohort study, BMI serial measurements are useful not only for the prediction of MS and its components in childhood but also useful for predicting risk at adulthood ${ }^{77}$.

Though BMI is useful and is commonly used but there are certain limitations which are associated with it. Relationship of BMI and body fat is effected by various environmental factors like physical activity, gender, age and ethnicity ${ }^{78}$. Thus while interpreting BMI of a subject for predicting of MS the above factors should also be considered.

\subsubsection{Waist-to-height ratio}

WHtR used for central obesity detection and its associated health risks was first proposed in the mid $1990 \mathrm{~s}^{79}$. This anthropometric measure is considered to be more sensitive than BMI for early warning of health risk and can predict morbidity and mortality in longitudinal studies often better than BMI. Also significant association has been seen with all the risk factors of obesity and MS with $\mathrm{WHtR}^{80}$. WHtR when compared with WC, the former is even more sensitive in several different populations possibly because it encompasses the adjustment to different statures ${ }^{(80,81,82)}$. Suitability of this measure has also been validated to predict cardiovascular risk factors with DEXA and bioelectrical impedance analysis ${ }^{83}$. WHtR has a potential for wider use as a simple and sensitive measure for identifying central obesity. This was proved while studying 3091 black and white children aged 4-18 yrs, where in the normal weight children with central obesity had adverse levels of cardio metabolic risk factor variables as compared to those without central obesity; the overweight/obese without central obesity had significantly lower levels in relation to those with central obesity $^{84}$. A study with a stratified cluster representative sample of 23422 Chinese children, aged 0-18 yrs, showed that waist-to-height ratio that is equal to 0.46 , could be taken as the optimal thresholds and there were significant differences for the average levels of systolic and diastolic blood pressure, serum triglyceride, high density lipoprotein cholesterol ${ }^{85}$. Similar results were seen in 1665 adolescents(13-15 yrs) from Hebei province in China; children with WHtR $\geq 0.46$ had significantly elevated levels of fasting plasma glucose and triglycerides and 
a lower level of HDL compared with the control group with $\mathrm{WHtR}<0.46^{86}$. Authors concluded that it is a significant predictor of the metabolic syndrome in obese youth by studing 109 obese boys and girls, aged 10-16.5 years in Australia ${ }^{87}$. Evidence from various researches and systematic review has suggested boundary value of 0.5 globally ${ }^{88,89}$. This anthropometric measure can be easily communicated and comprehend by all age groups with simple public health message: 'Keep your waist circumference to less than half your height ${ }^{90}$. As per the evidence from the Bogulas Heart study, BMI-for-age and waistto-height ratio do not differ in their abilities to identify children with adverse risk factors (lipids, fasting insulin, and blood pressures). However waist-to-height ratio should be preferred because of its simplicity ${ }^{(91,92)}$. It is not only appropriate tool for the research but also represents a powerful tool in the hands of pediatricians to identify obese children with high cardiovascular and metabolic risks to decide on further course of clinical investigations and interventions in these patients ${ }^{93}$.

\subsubsection{Neck Circumference (NC)}

This anthropometric measure provides additional information for CVD risk and is measured midway between the midcervical spine and midanterior neck, just below the laryngeal prominence ${ }^{94}$. NC measurement overcomes the problem of WC and waist to hip ratio as it involves no undressing and thus NC can be easily performed in winters and in busy primary care centres ${ }^{95}$. This method, is not also not effected by respiratory movements, being full or in hungry state ${ }^{(96,97)}$. NC shows very good inter and good intra-rater reliability, which does not require multiple measurements for precision and reliability compared with $\mathrm{WC}^{98}$. It has shown positive correlation with $\mathrm{WC}$, $\mathrm{BMI}$ in overweight and obese children and thus can be used as an additional and practical tool for overweight and obesity if age and gender adjusted cut off are available ${ }^{99}$. Similar results were published, where NC correctly identified high proportion of young children and adolescents who were overweight or obese (higher BMI scores) ${ }^{67}$. Hatipoglu et al. ${ }^{95}$ in their study of four hundred twelve overweight and obese patients (208 girls and 204 boys) and 555 healthy children (284 girls and 271 boys) aged 6- 18 years showed a significant and positive correlation between BMI-NC, BMI-WC and WC- NC ( $<<0.001)$; thus it can be used as a screening tool for evaluation of obesity $^{95}$. Though it is an index of upper body obesity, association of it with cardio metabolic risk factors (fasting plasma glucose, insulin, total cholesterol, triglyceride and high-density lipoprotein) have been studied by author in Turkey with 581 children aged between 5-18 yrs. Findings of study showed NC was negatively correlated with HDL cholesterol and positively correlated with all other parameters, with the exception of fasting plasma glucose in pubertal boys and girls and total cholesterol in pubertal girls ${ }^{100}$. Results were comparable with a study in Greece involving 324 children $3-19$ yrs $^{100}$.

Though NC is found to have good correlation with metabolic features risk among children and adolescents but the age, sex and region specific cut off data are lacking. Also analysis of data results can also be misinterpreted in case subject has goitre or other neck masses, neck deformity, or tracheostomy or cervical collar.

\section{Conclusion}

With change in lifestyle choices in $21^{\text {st }}$ century, there has been a shift from sound diets and physical activity centred environment, to an obesogenic environment leading to deteriorated health of children and adolescents. An example of a chronic disease observed in today's children related to this change is the MS ${ }^{101}$. MS involves constellation of CVD risk factors like obesity, high glucose level, high triglycerides and low HDL levels and there are studies indicating that MS appears even in childhood. Identification and prediction of MS at early stages is important due to sequential development of CVD and diabetes in adulthood with increased probability as compared to subjects without MS. Identifying subjects with MS through biochemical procedure is not a practical measure in epidemiological studies due to expensive, invasive techniques and the risk of contamination. Method which is suitable for predicting the subject at risk of developing MS is anthropometry. Through anthropometry, high risk subjects can be screened and further biochemical testing can be done. Although there is no perfect anthropometric method (waist circumference, BMI, waist to height ratio and neck circumference), errors could be reduced if precautions are taken such as choosing appropriate equipment, measurement protocol and providing regular training and standardisation of data collectors to maintain the validity and reliability of data. WC is a useful tool for screening early stages of metabolic aberrations but defining cut off points for defining obesity and overweight are complex; along with it, country specific cut off are lacking. BMI remains the most popular obesity 
measure, overcoming the disadvantages and limitations of waist circumference. However, a BMI percentile value serves only as an indicator of relative weight but cannot distinguish between the anatomic distribution of tissues (e.g., upper/lower, central/peripheral) and may not indicate the level of central adiposity, associated with CVD risk factors. Waist-to-height ratio is recently reported as a sensitive and effective global anthropometric index of fat distribution in children at population level. WHtR and WC are convenient screening measures to assess the predictive increase in obesity and associated CVD risk factors in school screening. This tool can be easily interpreted by simple public health message "Keep the waist circumference to less than half of your height" ${ }^{\prime \prime}$. Another method useful for screening purpose is $\mathrm{NC}$ and it assesses upper fat distribution. It is easier to measure $\mathrm{NC}$ in comparison to waist circumference and waist to height ratio. Though the method is simple and is strongly associated in predicting the CVD risk factors among children and adolescents but the age, sex and region specific cut off and percentile are lacking. Following consideration should be kept in mind while selecting the anthropometric measure for screening of MS like age group, acceptance of method, measurement expertise, reference values for comparisons, availability of money and resources. However, WC has a significant positive correlation with triglycerides, fasting blood glucose and negative correlation with HDL-C than any other indices. But recommending any one anthropometric indices for prediction of MS is difficult because of insufficient data from cohort, case control and systematic reviews. Thus for better results, a combination of methods of generalised and abdominal obesity may be considered appropriate in prediction of MS rather than using either of them alone ${ }^{102,103}$. Once the MS is predicted, confirmation of it can be done by biochemical testing. Once identified with MS, health education programs should be initiated with aim of primary and primordial prevention of obesity.

\section{References}

1. Sarafidisa PA, Nilsson PM. The metabolic syndrome: a glance at its history. J Hypertens. 2006; 24(4):621-6.

2. Alberti KG, Zimmet P, Shaw J. The metabolic syndrome -a new worldwide definition. Lancet. 2005; 24-30; 366 (9491):1059-62.

3. Misra A, Chowbey P, Makkar BM, Vikram NK, Wasir JS, Chadha D, Joshi SR, Sadikot S, Gupta R, Gulat S and Munjal YP. Consensus Statement for diagnosis of obesity, abdominal obesity and the metabolic syndrome for asian indians and recommendations for physical activity, Medical and Surgical Management. J Assoc Physicians India. 2009; 57:163-70.

4. Zimmet P, Alberti KG, Kaufman F, Tajima N, Silink M, Arslanian S, Wong G, Bennett P, Shaw J and Caprio S. The metabolic syndrome in children and adolescents - an IDF consensus report. Pediatr Diabetes. 2007; 8(5):299-306.

5. Cook S, Weitzman M, Auinger P, Nguyen M and Dietz WH. Prevalence of a metabolic syndrome phenotype in adolescents: findings from the third National Health and Nutrition Examination Survey, 1988-1994. Arch Pediatr Adolesc Med. 2003; 157(8):821-7.

6. Eckel RH, Grundy SM, Zimmet PZ. The metabolic syndrome. Lancet. 2005; 22; 365(9468):1415-28.

7. Wang Y, Lobstein T. Worldwide trends in childhood overweight and obesity. Int J Pediatr Obes. 2006; 1(1):11-25.

8. Enas EA, Mohan V, Deepa M, Farooq S, Pazhoor S, and Chennikkara $\mathrm{H}$. The metabolic syndrome and dyslipidemia among Asian Indians: a population with high rates of diabetes and premature coronary artery disease. J Cardiometab Syndr. 2007; 2(4):267-75.

9. Pradeepa R, Prabhakaran D, Mohan V. Emerging Economies and Diabetes and Cardiovascular Disease. Diabetes Technol Ther. 2012; 14 Suppl 1:S59-67.

10. Abegunde D, Stanciole A. An estimation of the economic impact of chronic noncommunicable diseases in selected countries. World Health Organization, Department of Chronic Diseases and Health Promotion; 2006.

11. Bloom DE, Cafiero ET, McGovern ME, Prettner K, Stanciole A, Weiss J, Bakkila S, Rosenberg L. The economic impact of non-communicable disease in China and India: estimates, projections, and comparisons. PGDA. Working Paper No. $107 ; 2013$.

12. Tailor AM, Peeters $\mathrm{PH}$, Norat T, Vineis $\mathrm{P}$ and Romaguera D. An update on the prevalence of the metabolic syndrome in children and adolescents. Int J Pediatr Obes. 2010; 5(3):202-13.

13. Iamopas $\mathrm{O}$, Chongviriyaphan $\mathrm{N}$ and Suthutvoravut $\mathrm{U}$. Metabolic syndrome in Obese Thai children and adolescents. J Med Assoc Thai. 2011; 94 Suppl 3:S126-32.

14. Kapil U, Kaur S. Dyslipidemia amongst Obese Children in National Capital Territory (NCT) of Delhi. Indian J Pediatr. 2011; 78(1):55-7.

15. Singh R, Bhansali A, Rand S, Aggarwal A. Prevalence of metabolic syndrome in adolescents from a north Indian population. Diabet Med. 2007; 24(2):195-9.

16. Das UN. Is Metabolic syndrome $X$ an inflammatory condition? Exp Biol Med (Maywood). 2002; 227(11):989-97.

17. Barker DJ, Hales CN, Fall CH, Osmond C, Phipps K and Clark PM. Type 2 (non-insulin dependent) diabetes 
mellitus, hypertension, and hyperlipidemia (syndrome X): relation to reduced fetal growth. Diabetologia. 1993; 36(1):62-7.

18. Vikram NK, Pandey RM, Misra A, Goel K, Gupta N. Factor analysis of the metabolic syndrome components in urban Asian Indian adolescents. Asia Pac J Clin Nutr. 2009; 18(2):293-300.

19. Gunnell DJ, Frankel SJ, Nanchahal K, Peters TJ, Davey Smith G. Childhood obesity and adult cardiovascular mortality: a 57-y follow-up study based on the Boyd Orr cohort. Am J Clin Nutr. 1998; 67(6):1111-8.

20. Ghassemi H, Harrison G, Mohammad K. An accelerated nutrition transition in Iran. Public Health Nutr. 2002; 5(1A):149-55.

21. Rizzo ACB, Goldberg TBL, Silva CC, Kurokawa CS, Nunes HRC, Corrente JE. Metabolic syndrome risk factors in overweight, obese, and extremely obese brazilian adolescents. Nutr J. 2013; 12:19.

22. Wang Q, Yin J, Xu Lu, Cheng H, Zhao X, Xiang H, Lam HS, Mi J, Li M. Prevalence of metabolic syndrome in a cohort of Chinese schoolchildren: comparison of two definitions and assessment of adipokines as components by factor analysis. BMC Public Health. 2013; 13:249.

23. Li Y, Yang X, Zhai F, Kok FJ, Zhao W, Piao J, Zhang J, Cui $\mathrm{Z}, \mathrm{Ma}$ G. Prevalence of the metabolic syndrome in Chinese adolescents. Br J Nutr. 2008; 99(3):565-70.

24. Gupta R, Misra A, Vikram NK, Kondal D, Gupta SS, Agrawal A, Pandey RM. Younger age of escalation of cardiovascular risk factors in Asian Indian subjects. BMC Cardiovascular Disord. 2009; 5(9):28.

25. Yatheesha BL, Borade A, Rajam L. Metabolic syndrome in the at risk for overweight and overweight children and adolescents. Pediatric oncall [serial online] 2010 [cited 2010 November 1]; 7. Art \# 65.

26. Saha AK, Sarkar N, Chatterjee T. Health consequences of childhood obesity. Indian J Pediatr. 2011; 78(11):1349-55.

27. Singh N, Parihar RK, Saini G, Mohan SK, Sharma N, Razak M. Prevalence of Metabolic syndrome in adolescents aged 10-18 years in Jammu, J and K. Indian J Endocrinol Metab. 2013; 17(1):133-7.

28. Andrabi SMS, Bhat MH, Andrabi SRS, Kamili MMA, Imran A, Nisar I, Nisar U. Prevalence of metabolic syndrome in 8-18-year-old school-going children of Srinagar city of Kashmir India. Indian J Endocrinol Metab. 2013; 17(1):133-7.

29. Malonda AA, Tangklilisan HA. Comparison of metabolic syndrome criteria in obese and overweight children. Paediatrica Indonesiana. 2010; 50(5):295-99.

30. Esmaillzadeh A, Mirmiran P, Azadbakht L, Etemadi A, Azizi F. High prevalence of the metabolic syndrome in Iranian adolescents. Obesity (Silver Spring). 2006; 14(3):377-82.
31. Kelishadi R, Ardalan G, Gheiratmand R, Adeli K, Delavari A, Majdzadeh R. Pediatric metabolic syndrome and associated anthropometric indices: CASPIAN Study. Acta Paediatr. 2006; 95(12):1625-34.

32. Barzin M, Asghari G, Hosseinpanah F, Mirmiran P, Azizi F. The association of anthropometric indices in adolescence with the occurrence of the metabolic syndrome in early adulthood: Tehran Lipid and Glucose Study (TLGS). Pediatr Obes. 2013; 8(3):170-7.

33. Wee BS, Poh BK, Bulgiba A, Ismail MN, Ruzita AT, Hills AP.2011. Risk of metabolic syndrome among children living in metropolitan Kuala Lumpur: A case control study. BMC Public Health 2011; 18(7):333.

34. Cruz ML, Weigensberg MJ, Huang TT, Ball G, Shaibi GQ, Goran MI. The metabolic syndrome in overweight Hispanic youth and the role of insulin sensitivity. J Clin Endocrinol Metab. 2004; 89(1):108-13.

35. Schumacher HI, Rivas NH, Rojas MR, Santamaría BM. Components of the metabolic syndrome among a sample of overweight and obese Costa Rican schoolchildren. Food Nutr Bull. 2009; 30(2):161-70.

36. Mehairi AE, Khouri AA, Naqbi MM, Muhairi SJ, Maskari FA, Nagelkerke N, Shah SM. Metabolic Syndrome among Emirati Adolescents: A School-Based Study. PLoS ONE. 2013; 8(2): e56159.

37. Sen Y, Kandemir N, Alikasifoglu A, Gonc N, Ozon A. Prevalence and risk factor of metabolic syndrome in obese children and adolescents in obese children and adolescents :the role of the severity of obesity. Eur J Pediatr. 2008; 167(10):1183-9.

38. Moran MR, V’azqez BS, Violante R, Romero FG. Metabolic syndrome among children and adolescents aged 10-18 years. Diabetes Care 2004; 27(10):2516-7.

39. Ryu SY, Kweon SS, Park HC, Shin JH, Rhee JA. Obesity and the metabolic syndrome in korean adolescents. J Korean Med Sci. 2007; 22(3):513-7.

40. Kim HM, Park J, Kim DH. Prevalence of the metabolic syndrome in Korean adolescents aged 12-19 years from the Korean National Health and Nutrition Examination Survey 1998 and 2001. Diabetes Res Clin Pract. 2007; 75: 111-14.

41. Seo SJ, Lee HY, Lee SW. The prevalence of the metabolic syndrome in Korean children and adolescents: Comparisons of the Criteria of Cook et al., Cruz and Goran, and Ferranti et al. Yonsei Med J. 2008; 30,49(4):563-72

42. You MA, Son YJ. Prevalence of metabolic syndrome and associated risk factors among Korean adolescents: Analysis from the Korean national survey. Asia-Pacific Journal of Public Health. 2012; 24(3):464-71.

43. Standl E. Aetiology and consequences of the metabolic Syndrome. Eur Heart J. 2005; 7 (Supplement D), D10-D13. 
44. Camhi SM, Kuo J and Young DR. Identifying adolescent metabolic syndrome using body mass index and waist circumference. Prev Chronic Dis. 2008; 5(4):A115.

45. Physical status: the use and interpretation of anthropometry. Report of a WHO Expert Committee. World Health Organ Tech Rep Ser. 1995; 854:1-452.

46. Ferreira AP1, Pitanga FJG, Moraes CF, Naves LA, Nóbrega OT, França NMD. Prediction of metabolic syndrome in children through anthropometric indicators. Arq Bras Cardiol. 2011; 96(2):121-5.

47. Pillai C, Udhoji P, Rathod S, Pillai K. Comparison of body mass index, body fat percentage and neck circumference as tools for evaluation of obesity. Natl J Physiol Pharm Pharmacol. 2012; 2(2):167-71.

48. Hashemipour M, Soghrati M, Ahmadi MM, Soghrati M. Anthropometric indices associated with dyslipidemia in obese children and adolescents: a retrospective study in isfahan. ARYA Atheroscler. 2011; 7(1):31-39.

49. Chuang SY, Pan WHP. Predictability and implications of anthropometric indices for metabolic abnormalities in children: nutrition and health survey in Taiwan elementary children, 2001-2002. Asia Pac J Clin Nutr. Asia Pac J Clin Nutr. 2009; 18(2):272-9.

50. World Health Organization (WHO) STEPS: Framework for Surveillance. WHO STEPwise Approach to Surveillance of Non-communicable Disease. (STEPS) World Health Organization. STEPwise approach to surveillance (STEPS). Geneva, World Health Organization; 2008.

51. NHLBI Obesity Education Initiative. The practical guide: Identification, evaluation and treatment of overweight and obesity in adults. National Institutes of Health (NIH) 2000 Publication Number 00-4084.

52. Westat Inc. National Health and Nutrition Examination Survey (NHANES) III. National Center for Health Statistics (NCHS), Centers for Disease Control and Prevention (CDC); 1998.

53. Croft JB, Keenan NL, Sheridan DP, Wheeler FC, Speers MA.Waist-to-hip ratio in a biracial population: measurement, implications, and cautions for using guidelines to define high risk for cardiovascular disease. J Am Diet Assoc. 1995; 95(1):60-4.

54. McCarthy HD. Body fat measurements in children as predictors for the metabolic syndrome: focus on waist circumference. Proc Nutr Soc. 2006; 65(4):385-92.

55. Expert Panel on Detection, Evaluation, and Treatment of High Blood Cholesterol In Adults. Executive summary of the third report of the national cholesterol education program (NCEP) expert panel on detection, evaluation and treatment of high blood cholesterol in adults (Adult Treatment Panel III). JAMA. 2001; 285(19):2486-97.
56. Lee S, Bacha F, Arslanian S. Waist circumference, blood pressure, and lipid components of the metabolic syndrome. J Pediatr. 2006; 149(6):809-16.

57. Bitsori M, Linardakis M, Tabakaki M, Kafatos A. Waist circumference as a screening tool for the identification of adolescents with the metabolic syndrome phenotype. Int J Pediatr Obes. 2009; 4(4):325-31.

58. Maffeis C, Pietrobelli A, Grezzani A, Provera S, Tato L. Waist circumference and cardiovascular risk factors in prepubertal children. Obes Res. 2001; 9(3):179-87.

59. Lee K, Song YM, Sung J. Which obesity indicators are better predictors of metabolic risk? Obesity (Silver Spring). 2008; 16(4):834-40.

60. Freedman DS, Serdula MK, Srinivasan SR, Berenson GS. Relation of circumferences and skinfold thicknesses to lipid and insulin concentrations in children and adolescents: the Bogalusa Heart Study. Am J Clin Nutr. 1999; 69(2):308-17.

61. Sellers EA, Singh GR, Sayers SM. Large waist but low body mass index: the metabolic syndrome in Australian Aboriginal children. J Pediatr. 2008; 153(2):222-7.

62. Misra A, Madhavan M, Vikram NK, Pandey RM, Dhingra V, Luthra K. Simple anthropometric measures identify fasting hyperinsulinemia and clustering of cardiovascular risk factors in Asian Indian adolescents. Metabolism. 2006; 55(12):1569-73.

63. Chu NF, Chin HC, Wang SC. Prevalence and anthropometric risk of metabolic syndrome in Taiwanese adolescents. ISRN Cardiol. 2011; 2011:743640.

64. Hirschler V, Maccallini G, Calcagno M, Aranda C, Jadzinsky M. Waist circumference identifies primary school children with metabolic syndrome abnormalities. Diabetes Technol Ther. 2007; 9(2):149-57.

65. Body fat distribution and noncommunicable diseases in populations: overview of the 2008 WHO Expert Consultation on Waist Circumference and Waist-Hip Ratio. Eur J Clin Nutr. 2010; 64(1):2-5.

66. Gibson RS. Principles of nutritional assessment. New York: Oxford University Press.2005, 2nd edn.

67. Nafiu OO, Burke C, Lee J, Voepel-Lewis T, Malviya S, Tremper KK. Neck circumference as a screening measure for identifying children with high body mass index. Pediatrics. 2010; 126(2):e306-10.

68. Widhalm K, Sch"onegger K, Huemer C, and Auterith A. Does the BMI reflect body fat in obese children and adolescents? A study using the TOBEC method, Int J Obes Relat Metab Disord. 2001; 25(2):279-85.

69. Kuczmarski RJ, Ogden CL, Guo SS, Grummer-Strawn LM, Flegal KM, Mei Z, Wei R, Curtin LR, Roche AF, Johnson CL. 2000 CDC growth charts for the United States: methods and development. Vital Health Stat 11. 2002; 246: 1-190. 
70. Tirosh A, Shai I, Afek A, Dubnov-Raz G, Ayalon N, Gordon B, Derazne E, Tzur D, Shamis A, Vinker S, Rudich A. Adolescent BMI trajectory and risk of diabetes versus coronary disease. N Engl J Med. 2011; 364(14):1315-25.

71. Mei Z, Grummer-Strawn LM, Pietrobelli A, Goulding A, Goran MI and Dietz WH.2002. Validity of body mass index compared with other body-composition screening indexes for the assessment of body fatness in children and adolescents. Am J Clin Nutr. 2002; 75(6):978-85.

72. US Preventive Services Task Force and Barton M. Screening for obesity in children and adolescents: US Preventive Services Task Force recommendation statement. Pediatrics. 2010 Feb; 125(2):361-7.

73. American Diabetes Association .Type 2 diabetes in children and adolescents. American Diabetes Association. Diabetes Care. 2000; 23(3):381-9.

74. Agirbasli M, Agaoglu NB, Ergonul O, Yagmur I, Aydogar H, Oneri T, Ozturk O. Comparison of anthropometric indices in predicting metabolic syndrome components in children. Metab Syndr Relat Disord. 2011; 9(6):453-59.

75. Garnett SP, Baur LA, Srinivasan S, Lee JW, Cowell CT . Body mass index and waist circumference in midchildhood and adverse cardiovascular disease risk clustering in adolescence. Am J Clin Nutr. 2007: 86(3):549-55.

76. Jung C, Fischer N, Fritzenwanger $M$, Figulla HR. Anthropometric indices as predictors of the metabolic syndrome and its components in adolescents. Pediatr Int. 2010 Jun;52(3):402-9.

77. Sachdev HPS, Osmond C, Chd F, Lakshmy R, Ramji S, Dey Biswas Sk, Prabhakaran D, Tandon N, Reddy Ks, Barker Djp, Bhargava SK. Predicting adult metabolic syndrome from childhood body mass index. Arch Dis Child. 2009; 94(10):768-74.

78. Bhurosy T, Jeewon R. Pitfalls of using Body Mass Index (BMI) in assessment of obesity risk. Curr Res Nutr Food Sci. 2013; 1(1):71-6.

79. Ashwell M, Lejeune S, McPherson K. Ratio of waist circumference to height may be better indicator of need for weight management. BMJ. 1996; 312(7027):377.

80. Patel S, Unwin N, Bhopal R, White M, Harland J, Ayis SA, Watson W, Alberti KG. A comparison of proxy measures of abdominal obesity in Chinese, European and South Asian adults. Diabet Med. 1999; 16(10):853-60.

81. Lin WY, Lee LT, Chen CY, Lo H, Hsia HH, Liu IL, Lin RS, Shau WY, Huang KC. Optimal cut-off values for obesity: using simple anthropometric indices to predict cardiovascular risk factors in Taiwan. Int J Obes Relat Metab Disord. 2002; 26(9):1232-8.

82. Sayeed MA, Mahtab H, Latif ZA, Khanam PA, Ahsan KA, Banu A, Azad Khan AK. Waist-to-height ratio is a better obesity index than body mass index and waist-to-hip ratio for predicting diabetes, hypertension and lipidemia. Bangladesh Med Res Counc Bull. 2003; (1):1-10.

83. Lee K. Waist circumference percentile criteria for the pediatric metabolic syndrome in Korean adolescents. Asia Pac J Clin Nutr. 2008; 17(3):422-8.

84. Mokha JS, Srinivasan SR, Dasmahapatra P, Fernandez C, Chen W, Xu J, Berenson GS. 2010.Utility of waist-toheight ratio in assessing the status of central obesity and related cardiometabolic risk profile among normal weight and overweight/obese children: The Bogalusa Heart Study. BMC Pediatr. 2010; 10:73.

85. Meng LH, MI J, Cheng H, Hou DQ, Zhao XY, Ding XY. Using waist circumference and waist to height ratio to access central obesity in children and adolescents. Chin J Evid Based Pediatr. 2007; 2: 245-52.

86. Lu Q, Iseli TJ, Yin FZ, Ma CM, Liu BW, Lou DH, Liu XL. The Relationship between the Waist-to-Height Ratio and Glucose and Lipid Metabolism in Han Adolescents. Indian J Pediatr. Indian J Pediatr. 2010; 77(5):547-50.

87. Nambiar S, Truby H, Davies PS, Baxter K. Use of the waist-height ratio to predict metabolic syndrome in obese children and adolescents. J Paediatr Child Health. 2013; 49(4):E281-7.

88. McCarthy H, Ashwell M. Trends in waist: Height ratios in British children aged 11-16 over a two-decade period. Proc Nutr Soc Am. 2003; 62:46.

89. Browning LM, Hsieh SD, Ashwell M. A systematic review of waist-to-height ratio as a screening tool for the prediction of cardiovascular disease and diabetes: 0.5 could be a suitable global boundary value. Nutr Res Rev. 2010; 23(2):247-69.

90. Ashwell M, Hsiesh SD. Six reasons why the waist-to-height ratio is a rapid and effective global indicator for health risks of obesity and how its use could simplify the international public health message on obesity. Int J Food Sci Nutr. 2005; 56(5):303-7.

91. Freedman DS, Kahn HS, Mei Z, Grummer-Strawn LM, Dietz WH, Srinivasan SR, Berenson GS .Relation of body mass index and waist-to-height ratio to cardiovascular disease risk factors in children and adolescents: the Bogalusa Heart Study. Int J Food Sci Nutr. 2005; 56(5):303-7.

92. Kahn HS, Imperatore G and Cheng YJ.A populationbased comparison of BMI percentiles and waist-to-height ratio for identifying cardiovascular risk in youth. J Pediatr. 2005;146(4):482-8.

93. Santoro N, Amato A, Grandone A, Brienza C, Savarese $\mathrm{P}$, Tartaglione N, Marzuillo P, Perrone L, Giudice EM. Predicting metabolic syndrome in obese children and adolescents: look, measure and ask. Obes Facts. 2013; 6(1):48-56. 
94. Cornier M-A, Despre's J-P, Davis N, Grossniklaus DA, Klein S, Lamarche B, Lopez-Jimenez F, Rao G, St-Onge M-P, Towfighi A, Poirier P; on behalf of the American Heart Association Obesity Committee of the Council on Nutrition, Physical Activity and Metabolism, Council on Arteriosclerosis, Thrombosis and Vascular Biology, Council on Cardiovascular Disease in the Young, Council on Cardiovascular Radiology and Intervention, Council on Cardiovascular Nursing, Council on Epidemiology and Prevention, Council on the Kidney in Cardiovascular Disease, and Stroke Council. Assessing adiposity: a scientific statement from the American Heart Association. Circulation. 2011; 124(18):1996-2019.

95. Hatipoglu N, Mazicioglu M. Kurtoglu S, Kendirci M. Neck circumference: an additional tool of screening overweight and obesity in childhood. Eur J Pediatr. 2010 Jun; 169(6):733-9.

96. Ben-Noun L, Sohar E, Laor A. Neck circumference as a simple screening measure for identifying overweight and obese patients. Obes Res. 2001; 9(8):470-7.

97. Ben-Noun L, Laor A. 2003. Relationship of neck circumference to cardiovascular risk factors. Obes Res. 2003; 11(2):226-31.
98. LaBerge RC, Vaccani JP, Gow RM, Gaboury I, Hoey L, Katz SL. Inter- and intrarater reliability of neck circumference measurements in children. Pediatr Pulmonol. 2009; 44(1):64-9.

99. Kurtoglu S, Hatipoglu N, Mazicioglu MM, Kondolot M. Neck circumference as a novel parameter to determine metabolic risk factors in obese children. Eur J Clin Invest. 2012 ; 42(6):623-30.

100. Androutsos O, Grammatikaki E, Moschonis G, RomaGiannikou E, Chrousos GP, Manios Y, Kanaka-Gantenbein C. Neck circumference: a useful screening tool of cardiovascular risk in children. Pediatr Obes. 2012 Jun; 7(3):187-95.

101. Brandon LJ, Proctor L. Lifestyle choices Influence obesity and the metabolic syndrome in children. ACSM's Health \& Fitness J. 2008; 12(4):13-17.

102. Ardern CI, Katzmarzyk PT, Janssen I, Ross R. Discrimination of health risk by combined body mass index and waist circumference. Obes Res. 2003; 11(1):135-42.

103. Janiszewski PM, Janssen I, Ross R. 2007. Does waist circumferencepredictdiabetesandcardiovasculardiseasebeyond commonly evaluated cardiometabolic risk factors? Diabetes Care. 2007 Dec; 30(12):3105-9. 